Revue de l'Institut des langues et cultures

d'Europe, Amérique, Afrique, Asie et Australie

$31 \mid 2018$

Récits fictionnels et non fictionnels liés à des

communautés professionnelles et à des groupes spécialisés

\title{
British and American Diplomatic Memoirs as Factual Narratives: A Resource for the Linguistic and Cultural Analysis of the Specialised Domain of Diplomacy
}

Les mémoires de diplomates américains et britanniques comme récits factuels: une ressource pour analyser la langue-culture spécialisée du domaine de la diplomatie

Jessica Stark

\section{CpenEdition}

\section{Journals}

Electronic version

URL: http://journals.openedition.org/ilcea/4680

DOI: 10.4000/ilcea.4680

ISSN: 2101-0609

Publisher

UGA Éditions/Université Grenoble Alpes

Printed version

ISBN: 978-2-37747-043-3

ISSN: $1639-6073$

\section{Electronic reference}

Jessica Stark, «British and American Diplomatic Memoirs as Factual Narratives: A Resource for the Linguistic and Cultural Analysis of the Specialised Domain of Diplomacy », ILCEA [Online], 31 | 2018, Online since 06 March 2018, connection on 19 April 2019. URL : http://journals.openedition.org/ ilcea/4680; DOI : 10.4000/ilcea.4680

This text was automatically generated on 19 April 2019

(C) ILCEA 


\section{British and American Diplomatic Memoirs as Factual Narratives: A Resource for the Linguistic and Cultural Analysis of the Specialised Domain of Diplomacy}

Les mémoires de diplomates américains et britanniques comme récits factuels : une ressource pour analyser la langue-culture spécialisée du domaine de la diplomatie

Jessica Stark

\section{Introduction}

1 In an essay on the life of British statesman Lord Castlereagh, ${ }^{1}$ Lord Salisbury comments on the diplomat's "ephemeral" professional legacy, leaving "nothing which art can illustrate, or tradition retain, or history portray" (Bayne, 2010: XIV). Yet retired diplomats belie this assumption by often being prolific writers, as British diplomatic historian Steiner puts it: "Old diplomats do not die; they write their memoirs." (1994: 167) Diplomats are indeed proficient memorialists: at our most recent count, approximately 140 British and American diplomatic memoirs and autobiographies have been published since the mid-nineteenth century.

2 The diplomatic field is easily distinguishable from comparable specialist domains studied in ESP such as the legal or the medical domains, as its relationship to disciplinary knowledge is not one of exclusivity but of inclusivity: diplomats throughout their careers cultivate different areas of specialist knowledge (European affairs, trade, arms control, etc.) and possess "deep skills in a few areas, plus wide-even-if-shallow lateral skills in other fields" (Rana, 2011: 17). Diplomatic knowledge is not only technical but also socio- 
linguistic, intercultural and procedural (mastery of bilateral and multilateral diplomatic mechanisms for negotiation and routine intergovernmental communication, for example). Although memoirs are not fiction per se, they do, to some extent, tell a story and may invite, as such, some comparison to the specialised narrative of fiction à substrat professionnel or FASP (Petit, 1999). However, given their composite knowledge base, professional diplomatic narratives are likely to depict specialised discursive and professional practices differently from the specialised FASP narrative which often makes use of passages where specialised terminology features heavily. Yet, in the same way as FASP mirrors the professional environment it fictionalises, the diplomatic memoir as a "factual narrative" (Genette, 1990) provides a window into the diplomatic profession, explaining professional routines, cultural norms and discursive practices. A significant difference between the diplomatic memoir and FASP, however, is that a greater number of diplomats become memorialists than other professionals do fiction writers.

The longevity and recurrence of the diplomatic memoir suggest that it may constitute a specialised genre in its own right. In order to explore this hypothesis, we constituted a corpus of 28 British and American diplomatic memoirs published since the year $2000 .^{2}$ The post-World War II settlement can be seen as a turning point in diplomatic practice, with the development of multilateral diplomacy following the creation of the United Nations in 1945. Memoirs published from the year 2000 onwards are therefore more likely to retell diplomatic careers framed by this historical context, as diplomat-memorialists are often retired and narrate experiences spanning a thirty- to forty-year career. Approximately 70 British and American diplomatic memoirs have been published since the beginning of the twenty-first century. We selected 28 of them in view of a synchronic, qualitative analysis, with a relatively even chronological distribution over the period and a close-to-equal number of British and American memoirs.

4 The research question we examine in this paper is to what extent the diplomatic memoir, as a possible specialised genre, reflects discursive and cultural practices inherent in the diplomatic professional domain. We first set out to determine a generic prototype for the diplomatic memoir before examining its "professional substratum" (Petit, 1999) and how it exemplifies specialised diplomatic practice, knowledge and language. Finally, we suggest some tentative connections between the professional culture of the British and American diplomatic domain and its narrative instantiations in the memoir.

\section{The generic prototype of the diplomatic memoir}

\subsection{A complex "polygenre"}

5 Unlike its sister genre the autobiography, the memoir has received little critical attention (Rak, 2004: 305) despite its ancient pedigree, first appearing in France at the end of the fifteenth century and retaining since then its status as an "almost timeless narrative model" (Jeannelle, 2008: 293). The diplomatic memoir can be considered a "micro-genre" within the broader category of political memoir which encompasses military, naval, diplomatic and bureaucratic memoirs (Egerton, 1994: XIII). Despite these neat cut-off points between the different micro-genres, the macro-genre "appropriates autobiography, biography, diary, history, political science, journalism and pamphleteering, to name only its nearest literary neighbours" (ibid.: XII). Thus, for Egerton, "political memoir [can] best be comprehended as a polygenre-a literary 
amalgam of diffuse elements" (ibid.: 23). Notwithstanding this apparent compositional heterogeneity, the memoir presents specific structural, thematic and stylistic regularities which may establish its credentials as a genre as we argue below.

The diplomatic memoir corresponds to the broader definition of the macro-genre given by Jeannelle:

Memoirs are a life narrative set in its historical condition in which individuals recount their journeys, caught up in the flow of events, as both actors and witnesses, and as the bearers of stories which give meaning to the past (2008: 13). ${ }^{3}$ [Our translation]

7 Unlike the autobiography, whose main theme is the development of an individual's personal identity over time, the memoir envisages the life narrative in relation to its public and collective dimension. The memoir thus builds a factual narrative on several levels-personal/autobiographical, historical, and professional-which explains its variegated nature. The compositional challenges of ordering a multi-layered account are channelled through the recurring use of certain thematic sequences and recourse to a clear structure as we shall now see.

\subsection{Thematic and structural patterning}

Drawing on the work of Maingueneau, Saber (2011: 42-44) insists on the importance in genre analysis of the notion of a "typicality scale": a given genre presents a certain number of recurring linguistic patterns which constitute the "genre specifications" ( cahier des charges), and remain flexible and open to variation from one text to another:

Discursive genres can be considered 'prototypical-stereotypical categories [...] definable by patterns or gradients of typicality, by bundles of recurring and predominant features rather than by very strict criteria. ${ }^{4}$ (Adam, 1999: 93-94 in Saber, 2011: 42) [Our translation]

9 We applied the generic specifications concept to our corpus in order to determine whether certain recurring structural, linguistic or thematic features formed a generic protocol. The diplomatic memoirs in our corpus all share a similar structure: the narrative follows a chronological order, usually spanning the entire career of the diplomat, including one or two chapters on childhood and education and one on retirement. On the whole, the scope of the memoir is a career in its entirety, allowing for reflexion and appraisal of the specificities of diplomacy as a profession. This structural choice mirrors the status of the authors: 26 out of our 28 authors can be considered career diplomats (as opposed to political appointees), or members of the diplomatic service for a significant part of their careers, and none of the memorialists currently serve as diplomats.

10 The diplomatic memoir also shares with the umbrella memoir genre regular thematic sequences such as thumbnail portraits of colleagues, descriptions of places and landscapes, anecdotes, and broad historical accounts (Jeannelle, 2008: 357). These thematic features are remarkably symmetrical from one diplomatic memoir to another and reflect a solid crystallisation of this group of texts into a coherent whole. As a result, each memorial narrative responds to the generic expectations of its readers, who are attracted to the memoir precisely because it promises to satisfy these requirements (ibid. ). 
11 Another recurring thematic and stylistic trait of the diplomatic memoir is its intertextuality. The main thematic focus of the memoir narrative (the memorialist) is usually depicted against a broader, collective discursive background, which continually reiterates a form of socio-professional cohesion (Jeannelle, 2008). According to Quinby:

Whereas autobiography promotes an ' $I$ ' that shares with confessional discourse an assumed interiority and an ethical mandate to examine that interiority, memoirs promote an 'I' that is explicitly constituted in the reports of the utterances and proceedings of others. (1992: 299)

This interdiscursive background is built up through multiple references to the published, written work of politicians, diplomats, journalists, academics and literary authors (Hurd, 2004: 288; Bauman, 2014: 2762-2766; Rickerd, 2012: 50). We also find numerous references to other political and diplomatic memoirs (Grove, 2005: 282; Barrington, 2014b: 5109-5113). These sources serve as interpretive guidelines reinforcing the idea that each diplomatic memoir represents the micro-genre as a whole, putting forward a coherent version of the professional diplomatic narrative respecting the correct codes. Each memorialist provides descriptions of a diplomatic professional cultural sphere based on shared group beliefs, references, and memories.

\subsection{Function}

13 Nearly all the memoirs in our corpus share an explicit statement of purpose presented in the first few pages, again pointing to a certain stability of the micro-genre. The specificity of the diplomatic memoir resides in its intermediate functional space between a subjective settling of scores, engaging with the discourse and actions of others, and an objective account of past foreign policy. The authors in our corpus often position themselves as observers, merely recounting the events they witnessed throughout their careers. Despite this claim for neutral observer status, our diplomat-memorialists provide background information deemed necessary to put their professional contributions in context, subtly promoting their own roles and occasionally admitting to mistakes made or lost opportunities (Harsha, 2015: 8829-8854; Barrington, 2014a: 2457-2460). References to the sources used (diaries, papers, diplomatic correspondence, government archives, and letters) serve as a guarantor of the narrative's historical accuracy, but are frequently framed by a double disclaimer that the memoir is not an objective historical account, nor a reflection of the opinions of the diplomat's foreign ministry. A final goal that is often evoked in the memoirs of our corpus is to allow readers insider access to the inner workings of the British and American diplomatic systems. The authors achieve this objective by presenting descriptive sequences where specialised practices, procedures, and language are detailed in the form of a FASP-like "professional substratum" (Petit, 1999) accompanying the professional narrative.

\section{The "professional substratum" of the diplomatic memoir}

\subsection{Specialised language and genres}

14 A close association between professional reality and fictional narrative strategy is at the heart of Petit's (1999: § 33) definition of the "FASP" thriller. The professional domain and 
its actors are the driving force behind the plot: professional objects, procedures, knowledge, and practices are described in detail and become the axes around which the narrative is articulated. In doing so, FASP provides distinct insights into different specialist domains. The diplomatic memoir, a non-fictional narrative, relies on slightly different techniques in its depiction of the professional domain. Specialist practices do not dominate the memoir to the same extent as in a FASP work of fiction, where they appear as a proliferation of details anchoring the narrative in a specific professional locale. There is, however, perhaps a greater emphasis on explaining specialist documents and lexis in the diplomatic memoir, which may be because a sizeable portion of a diplomat's knowledge is based on linguistic, discursive and genre competence.

Possible genres that seem specific to the diplomatic profession are frequently referred to in our corpus and are usually accompanied by explanations regarding the document's main purpose, structure, and style. The document which appears the most regularly in the memoirs is "the diplomatic telegram" (for the British Foreign and Commonwealth Office) or "diplomatic cable" (U.S. Department of State). The "lifeblood of any decent diplomatic machine", the telegram is "a collective classified message, as tautly drafted as possible, sent from overseas posts to London and vice versa [...] analysing events in the host country and making recommendations for policy" (Cowper-Coles, 2012: 6, 295). Another frequently recurring potential genre in the corpus is "the diplomatic note" (Wilkowski, 2008: 230; Murray, 2006: 39), defined by Berridge and James (1999: 172) as "a strictly formal, third person, no-frills communication which is sometimes known as a note verbale [...], the customary mode of written communication between an embassy and a ministry of foreign affairs". The corpus also enables us to flesh out definitions of other diplomatic documents. Berridge and James' definition of a "demarche" as "an initiative taken by a diplomat, which may be anything from a suggestion to a threat" (ibid $\therefore 60$ ), does not suggest that a demarche can be a collective action, although references to this document in our memoirs do point that way. Thus, our corpus provides precious information on contexts of use as well as on the appraisal diplomats themselves have of the documents they produce and of the structural constraints internalised by the diplomatic community. Rickerd provides a good example of this in his memoir when describing the annual review (or report):

For decades it was a tradition-indeed a requirement-that British Ambassadors and High Commissioners write an Annual Review to the Office setting out the year's key events in their host country, summarising the state of relations with the UK and taking a guess at what might happen in the year to come (the latter section became known as the 'Whither Ruritania?' passage). (Rickerd, 2012: 41)

Specialised diplomatic lexis is envisaged in much the same way as diplomatic documents. Specialised terms do not pepper the diplomatic narrative in the same way as in a FASP work of fiction, where they serve the stylistic purpose of adding authenticity and anchoring the narrative in a specific setting, first and foremost because diplomatic language does not share the same amount of specialised terminology as the medical domain for example, a typical FASP setting. It would perhaps be more fitting to refer to specialised lexis rather than to specialised terminology in the case of diplomacy. That being said, we find numerous explanatory sequences in the memoirs aimed at rendering diplomatic language more explicit. References to diplomatic language cover three main areas: (a) terms referring to international diplomatic convention and practice such as casus belli, "withdrawal of ambassadors", "material breach", "back-channel message", "diplomatic status", etc.; (b) terms referring to the diplomatic apparatus of a state or 
political organisation in a foreign ministry or embassy (residence, chancery, chargé d'affaires ad interim, political counsellor, High Commission, country director); and finally, (c) more culture-specific terms that refer to British or American diplomatic traditions or practices ("diplomatic pouch/bag", "red box", "familiarisation visit", etc.). The fact that these lexical items are accompanied by explanations points to their specificity and possible status as specialised terms, as the following definition of "agrément" illustrates:

But, out of the blue, in the early autumn of 2002, my staff told me that the Foreign Office had officially sought what is known as agrément from the US State Department for David Manning to replace me as ambassador in August 2003. This is the process by which governments are asked to approve the appointment of a new ambassador. (Meyer, 2005: 273)

A final exemplification of specialised lexis in the diplomatic domain is the frequent use of acronyms such as "CODEL"-congressional delegation (Meara, 2006: 150), "MIFT"-my immediately following telegram (Murray, 2006: 61), "DEYOU"-a telegram which can be decrypted only with the ambassador present (Cowper-Coles, 2012: 61), or "CMD"-Chef de Mission Diplomatique (Murray, 2006: 26).

\subsection{Specialised practices and knowledge}

The memoirs in our corpus all seem to share a pedagogic objective aimed at rendering diplomatic activity transparent for the layman, possibly as a way of combatting an underlying prejudice that diplomacy is an arcane and obscure profession. They contain descriptive sequences explaining typical diplomatic practices, the mechanisms of multilateral and bilateral diplomacy, as well as diplomatic conventions and protocol that remain important to the profession. We often find job-profile type descriptions which sum up the main responsibilities and goals of a particular diplomatic posting. "Typicalday" narratives are another strategy used to shed light on a diplomat's routine, as in this example taken from Grove's memoir recounting his experience as American consul general in Jerusalem:

I began a typical day with an informal staff meeting in my office after reading the overnight cables from Washington and from other posts in the region. I might next meet with Palestinians and then have lunch with a visiting American, a journalist, or Sam Lewis if he was in town. [...] Afternoons might be devoted to visiting mayors on the West Bank and observing settlements to report on new activities. At the end of the day I dictated the cables [...] that needed to go out and mused about things in general with Jock. (2005: 226)

The multilateral negotiating process is not generally described in minute detail. One of the most salient aspects of multilateral diplomacy for our memorialists is the arduous transaction process involved in agreeing on "common language" for future commitments or agreements (Wilkowski, 2008: 316; Hurd, 2004: 216), which takes the form of "bracketing", as Bayne explains:

We began by writing phrases on a blackboard, for the Russians to amend and endorse before they went down on paper. Next we converted these to sentences, with any disputed wording replaced by dots [...]. We constructed a complete agreement, full of dots [...] then we went back over this again, replacing the dots by agreed language where possible or by alternative allied and Russian proposals in brackets. (2010: 72) underlining the collective aspect of diplomatic drafting, it illustrates that in multilateral 
diplomacy tensions can crystallise around certain terms, endowing them with specific meaning and performative power.

Finally, the memoirs in our corpus contain numerous references to diplomatic traditions and protocol such as the impossibility for diplomats to accept foreign decorations which, according to Barrington (2014a: 3645-3646), goes back to "the principle enunciated by Queen Elizabeth I that 'I will not allow my dogs to wear other people's collars"'. It is striking that the diplomatic conventions which appear most systematically in the memoirs are those involving ritualised forms of social interaction such as the customary round of "diplomatic calls" newly arrived diplomats are expected to make on other diplomatic colleagues and important contacts (Perkins, 2006: 381), the schedule of appointments with relevant home government departments and companies the diplomat follows before travelling to post (Meyer, 2005: 52), and the farewells to diplomatic colleagues upon leaving post or retiring (Meyer, 2005: 75; Hurd, 2004: 135). The importance of maintaining valuable social relationships is more than just a protocol requirement; it is an important feature highlighted by our authors in their portrayal of diplomatic professional culture. Such depiction of diplomatic culture is more complex than a simple, descriptive characterisation because it obeys a higher imperative as part of a defence of the diplomatic profession that oscillates between overt praise and a repositioning of the individual diplomat, constrained by a set of strictly codified professional cultural norms.

\section{Connection and disconnection between professional culture and professional life narrative}

\subsection{Reifying diplomatic culture through the memoir}

Intuitively, given the long history of the diplomatic profession-generally argued to have emerged with the creation and spread of permanent resident embassies in Europe in the mid-fifteenth century (Berridge, 2010)-the existence of a specific "diplomatic culture" among professional diplomats, sharing the goal of successfully and peacefully implementing their government's foreign policy through contact with other states or political entities, is highly probable. However, diplomatic culture has been deemed a "sponge word [that] can soak up a variety of operational meanings but at some saturation point begins to leave a logical and functional mess behind" (Der Derian, 1987: 31). In international relations studies the notion of diplomatic culture is nonetheless gaining ground (Sharp, 2004: 363) and generally refers to

the accumulated communicative and representational norms, rules, and institutions devised to improve relations and avoid war between interacting and mutually recognizing political entities (Wiseman, 2005: 409).

Diplomatic culture is thus understood by international relations scholars at a global level, shaped by the "diplomatic corps" of all diplomats worldwide and potentially resonating or conflicting with national cultures.

Writing a diplomatic memoir can be seen as a professional ritual for diplomats who have reached the end of their careers. Additionally, the memoir constitutes an ethnographic resource for better understanding the intersection or separation between national British and American cultures and the professional organisational cultures of the British Foreign and Commonwealth office and of the American State Department. The stability of the 
diplomatic memoir can also be seen in the homogenous portrayal of the diplomatic profession, a laudatory description of an often criticised occupation.

\subsection{A collective apologia of a "people-intensive" profession (Ferch, 2013: 38)}

Auwers and Biltekin (2012: 182), in a study of twentieth century Belgian and Swedish diplomatic memoirs, show that democratisation processes throughout the period led diplomats to write memoirs as a way of upholding their profession. This defensive stance, which seems to be a staple in diplomatic memoirs, draws on the rhetorical strategies of the apologia genre, defined as "a public speech of self-defense" (Ware \& Linkugel, 1973: 274) in response to a perceived attack. One of the most frequent devices used in our corpus is tacit rebuttal: diplomat-memorialists are careful, for example, to underline that taxpayers' money is not frittered away on vacuous and expensive cocktail receptions and that their sometimes modest social backgrounds did not preclude them from joining the ministry of foreign affairs (Charlton, 2016: 291-295), thus providing a corrective to some of the more pervasive stereotypes about the diplomatic profession. Another strategy used in the corpus is what Ware and Linkugel (1973: 278) call "differentiation", a "cognitively divisive strategy" which leads the audience to separate a fact or object from one context and place it in another, different context thus altering its meaning. One example is the utility of diplomatic protocol, which should be seen not in the context of ancient tradition but in that of cross-cultural communication. Repeatedly, we are told that what could be mistaken for needless flummery or outdated pomp and circumstance, such as the ceremonious presentation of diplomatic credentials to the head of state or government, a ritualistic event finely tuned to the accrediting country's protocol, needs to be interpreted as a symbolic communicative exchange of meaning between countries or governments.

Consequently, the symbols and rituals of the diplomatic profession are presented as meaningful and contribute to a more general argument throughout the memoirs: the diplomatic profession is relevant, necessary and mobilises specific skill-sets. The perceived coherence of diplomatic work tallies with a remarkably laudatory celebration of the profession. To cite just one example among many, Cowper-Coles describes his memoir as

a love letter to an institution-the Foreign Office [...]. For thirty-three years, I looked forward almost every working day to going into the office, or embassy, or wherever work took me. I was never bored. And I didn't just enjoy being a diplomat. I also believed that what I did as a diplomat mattered in small but important ways. (2012: XI)

A career in diplomacy is portrayed as being worthwhile, varied, and ultimately extremely fulfilling (Wilkowksi, 2008: 163; Meara, 2006: 97; Carrick, 2012: 154-158).

One possible reason for this widely shared career satisfaction could be the cohesive professional (and personal) networks built up by diplomats throughout their careers. Diplomacy is frequently described as relying heavily, even exclusively, on people-topeople relationships. The Foreign and Commonwealth office and State Department figure as "collegial" organisations, a "family" and a "club", structured around specific norms and practices including the perpetuation of a collective work ethic. The memorialist's 
entry to the exclusive diplomatic club is symbolised by a formal letter of appointment in the British case and by taking an "oath of office" in the American.

The proclaimed "family spirit" within the two organisational structures (British and American) is not just a superficial sentiment but can be linked to subtle forms of norm transmission and inculcation. Throughout the memoirs of our corpus, diplomacy is presented as something one "learns on the job" through mentoring by senior colleagues, suggesting a process of acculturation to the organisational norms, practices, and values inherent to "officemanship" (Cowper-Coles, 2012: 4). Diplomats are also mentored in order to reach the required level of linguistic and genre competence. We often read recollections of the diplomat's first attempts at drafting a telegram (Rickerd, 2012: 11; Perkins, 2006: 192), such as this example from Barrington's memoir:

I reported to one of the two Assistant Heads of Northern Department, Christopher McAlpine, from the contractor family. He was patient with me but had much to teach. Typically he would attack my drafts with lines, brackets and excisions so that sometimes only a few words in the middle of the page survived. (2014b: 825-855)

Despite being a "murderously competitive" profession (Ortiz, 2005: 207-208), references to diplomatic colleagues as well as to countless "friends" encountered in diplomatic postings present a running leitmotif in the corpus. Rather than settling scores, colleagues and friends are mentioned in positive terms as unique individuals who add up to form interpersonal networks which give structure and meaning to the diplomat's geographical rotation through different posts. This is manifest in the acknowledgments and dedication pages forming the memoir's paratext (Genette, 1982). Diplomatic colleagues are typically described with "affection, gratitude and admiration" (Talbott, 2003: 8036-8038). The international diplomatic corps is also portrayed in a positive light as a collective which creates a collegial working atmosphere that facilitates fruitful diplomatic endeavours (Burrows, 2001: 158; Bayne, 2010: 67).

\subsection{From heroes and thumbnails to professional cultural values}

31 The notion of the "diplomatic hero" appears to be a popular one among our diplomatmemorialists who use the term explicitly to refer to certain colleagues (Barrington, 2014b: 1711-1712). Diplomats who have made their mark on history, such as Henry Kissinger "the unrivalled philosopher of foreign policy" (Hurd, 2004: 571), Jean Monnet (Barrington, 2014a: 4232-4234), or George Kennan (Talbott, 2002: 305-307), are also revered. More than passing references, diplomatic heroes serve as a way of showcasing the qualities of the ideal diplomat through thumbnail descriptions, as illustrated by the two following prototypical examples from our corpus:

He was an excellent negotiator, being calm, patient and ingenious, and enjoyed the Prime Minister's total confidence. (Bayne, 2010: 144)

Hammarskjöld possessed qualities which [...] included a great capacity for hard work, a highly educated and sensitive mind, an interest in and commitment to the philosophical wisdom of different civilisations, and a personal dignity which required no buttressing with pomp and protocol. (Hurd, 2004: 158)

The repeated use of these thematic sequences gives the authors an opportunity to work out the diplomatic profession's most cherished values such as professional integrity, the principle of free comment during the policy-making process, and a commitment not to criticise policy decisions once they have been taken (Burrows, 2001: 22; Perkins, 2006: 242). Other qualities featured are political independence and impartiality as professional 
civil servants (Meyer, 2005: 10; Burrows, 2001: 175), a distrust of ideology (Cowper-Coles, 2012: 122), patriotism and loyalty to the home nation's best interests (Grove, 2005: 256), the importance of personal progress, learning curves and growth (Bauman, 2014: 2085-2087; Rickerd, 2012: 146), and finally the mandarinate ethos of public service (Cowper-Coles, 2012: 294; Shepard, 2013: 2071-2077).

It is worth noting that the above values are generally construed in relation to the diplomat's national culture and not to a broader international diplomatic culture. Thus, their inclusion in the narrative may be partly reactive in nature and contribute to the overall apologia of the profession: diplomats define themselves as loyal, patriotic, and competent public servants so as to counteract pervasive stereotypes about them "going native" and defending their host country's interests to the detriment of British or American concerns. Nonetheless, diplomatic culture can be seen not only as on the defensive, but also as a culture which aspires to ideals and constructs a value-laden, normative discourse as a result. This raises the question of the degree to which the description of diplomatic culture in the memoir reveals a tension between aspirations and reality. Behind this primary tension there may lie a second, between the diplomat as an individual and as a member of the diplomatic mandarinate, bound by a constraining set of professional cultural norms.

\subsection{Geographical location, dislocation and symbolic positioning: a tentative form of self-assertion?}

The diplomatic profession is based on geographical mobility. The "mobility obligation" (Knott, 2015: 308-311) that diplomats accept when they enter the service means that their ministry of foreign affairs can send them anywhere in the world, thus separating the diplomatic service from the rest of the civil service. According to Neumann (2012: 169-170), the diplomat's mindset is articulated around a clear distinction between work done in the home capital (London or Washington D.C. in this case) and tasks accomplished abroad (in an embassy or international organisation for example). The abundant descriptions of place in our corpus mirror this contrast.

The spaces of the diplomat's home foreign ministry are depicted perhaps as a way of reifying the more abstract concept of bureaucratic hierarchy. The description of office space alludes to the overarching "building hierarchy" (Knott, 2015: 379-380) of the ministerial structure, with the lowest positions located on the ground floors, and in the case of the State Department, the most prestigious offices residing in the "aerie" (Shepard, 2013: 773-776) of the "seventh floor" (Ferch, 2012: 23). Moreover, a clear chain of command is enacted spatially every day through the process of diplomatic drafting which proceeds gradually upwards, from office to office, through modifications and corrections to an original draft provided by the diplomat's superiors.

Structural hierarchy is less apparent in the spatial descriptions of embassy homes and offices abroad. Ambassadorial residences and grounds are often sketched in minute detail from room to room, and feature lush gardens complete with exotic animals (Hurd, 2004: 115; Barrington, 2014a: 1532-1537). These idyllic depictions contrast with the "embassyas-a-fortress" metaphor which surfaces frequently in the corpus and portrays the diplomat as being trapped within a hostile environment: 
The children were to remain safely inside our fortress compound, behind the locked gate and under the protection of our thick razor wire walls. (Bauman, 2014: 338-387)

Barbed wire barriers outside the Embassy walls made the Embassy appear like a fortress, a point of contention with the Governor of Jakarta. (Harsha, 2015: 8073-8082)

We find numerous allusions to a professional space that is codified and structured in less apparent ways. The profession is regulated through internal documents such as the Diplomatic Service Procedure (Murray, 2006: 247-248), the Diplomatic Service Formbook (Cowper-Coles, 2012: 4) or the Foreign Affairs Manual (Mabbatt, 2013: 140-142). In order to gain entry to the American or British diplomatic services, candidates must undergo a rigorous "direct" or "positive" vetting process, frequently cited in the memoirs (Knott, 2015: 133-137; Meara, 2006: 88). Diplomats at post are also constrained by the potential discrepancies between the information they gather from the field relevant for policymaking and the political line being taken back in London or Washington, making it difficult for them to question their superiors. According to Perkins:

Political officers find that truthful reporting can be risky to a career when he or she reports information that disagrees with the opinion of the ambassador or Washington officials. More than one political officer caught in that predicament has been tempted to adopt Emily Dickinson's poetic advice-"tell the truth, but tell it slant". (2006: 140-141)

As a result, the memoir occasionally takes on a confessional role as a repository where diplomats can admit how they deviated from the norms of diplomatic behaviour and culture, as Meyer confides in his memoir:

There is a long tradition of internecine warfare between the State Department and the Defense Department. Up to a point the embassy expected it and was used to dealing with it. But, after $9 / 11$, it was different. The issue was war and peace. This heightened and exposed the tensions within the US administration. It sharpened and deepened the fault line. It made the challenge to British diplomacy immeasurably more complicated. It forced me to operate in a way that took me to the limit of what is permissible for an ambassador. My sleeve began to touch the machinery. (2005: 221)

Perhaps this use of the memoir as a repository reflects the tendency diplomats have to put down in writing what they feel needs to be said, thus proving the importance of written communication (and of the famous "telegram" in particular) in the diplomatic mindset. Throughout the corpus, diplomats cite the telegrams they wrote in response to a particular situation, almost as a form of emotional release. Meara provides a good example of this use of the diplomatic telegram:

After that meeting, I returned to the embassy and wrote a very emotional cable about my day on the Coco. I deliberately gave it a very low classification and marked it for wide distribution in the embassy and in Washington-I wanted to share my epiphany with my colleagues. (2006: 159)

\section{Conclusions}

In his seminal work on specialised fiction or "FASP", Petit (1999: § 68) reminds us that the specialised discourse within the FASP genre does not have exactly the same status as nonfictional specialised discourse: "It does indeed present a certain number of characteristics pertaining to specialised discourse (terminological, phraseological elements, etc.), but does not itself constitute a genre or a recognised type of specialised discourse." ${ }^{5}$ We 
would argue that the diplomatic memoir, a non-fictional, professional life narrative regularly practiced by the British and American diplomatic community, constitutes a semi-specialised genre within the diplomatic domain. For the diplomatic memoir genre to be considered "specialised" one could argue that it needs to serve the domain's overarching purpose, which we posit to be the realisation of a political entity's foreign policy objectives through peaceful means. To the extent that not all diplomats write memoirs and that the memoir genre is not a routine document produced by working diplomats on a regular basis, the specialisation of the memoir genre appears rather limited.

41 Nonetheless, the genre may serve secondary purposes which contribute to the overall goal of effective diplomacy. By putting forward a robust defence of the profession, diplomat-memorialists may be strengthening the assertion of a professional sense-of-self, encouraging colleagues or future diplomats to engage in a diplomatic career. They thus preserve, albeit indirectly, their professional niche as foreign policy experts at a conjuncture which has seen the diplomat's professional territory increasingly impinged on by competing foreign policy pundits and Non-Governmental Organisations. An additional argument in favour of a form of specialisation of the memoir genre resides in its archival value. The memoirs of our corpus document foreign policy decisions and the context surrounding them, as well as diplomatic linguistic and professional practices as they have evolved over the past fifty to sixty years. In so doing, they provide a repository of knowledge for future diplomats in a profession which still relies to a large extent on on-the-job training.

42 Furthermore, the diplomatic memoir exemplifies one of the functions of the memoir analysed by Hart (1979: 195): "the personalizing of history; the historicizing of the personal [...], the personal act of repossessing a public world, historical, institutional, collective". The diplomat-memorialist portrays a professional diplomatic culture structured around shared constraints (bureaucratic hierarchies, discursive dos and don'ts), values, references, and beliefs, tapping into a shared interdiscursive background guaranteeing the profession's coherence and testifying to the importance of the social, collective dimension of the diplomatic domain. Rather than a "personalizing of history" we have perhaps a personalisation of the profession, through a discrete affirmation of the individual's position within the bureaucratic structure, characterised by a specific career trajectory and occasional leeway to manoeuver in undiplomatic ways.

43 However, it is important to remember that even though the diplomatic memoir can be considered a semi-specialised genre, it is one that is also written for non-specialists: the perceptions of diplomatic culture that can be gleaned from it are those that the diplomats choose to share with us and may be framed by higher objectives (defending the profession as a whole for example). That being said, it seems safe to argue that our diplomat-memorialists are acutely aware of there being a specific diplomatic cultural space which may remain impenetrable to "outsiders", if we are to believe Perkins:

The Foreign Service is not a culture in which when an order is given, something changes. It is an unusually closed system, difficult to penetrate by non-career officers and almost impossible to understand by people outside of the system. Even now, after serving as director general and spending a career of appointments all over the world, I find it very difficult to explain this extraordinary organization known as the Foreign Service. It is a country with its own mores, customs, and language. (2006: 441) 


\section{BIBLIOGRAPHY}

\section{CORPUS REFERENCES}

\section{BRITISH DIPLOMATIC MEMOIRS}

BARRINGTON Nicholas (2014a), Nicholas Meets Barrington: The Personal Journey of a Former Diplomat [Kindle edition], London and New York: The Radcliffe Press.

BARRINGTON Nicholas (2014b), Envoy: A Diplomatic Journey [Kindle edition], London and New York: The Radcliffe Press.

BAYNE Sir Nicolas (2010), Economic Diplomat, Durham, UK: The Memoir Club.

BURROWS Sir Bernard (2001), Diplomat in a Changing World, Spennymoor, County Durham, UK: The Memoir Club.

CARRICK Sir Roger (2012), Diplomatic Anecdotage: Around the World in 40 Years [Kindle edition], London: Elliott and Thompson Limited.

CHARLTON Alan (2016), Shaking my Briefcase [Kindle edition], Kibworth Beauchamp, Leicestershire: Troubador Publishing.

COWPER-COLES Sherard (2012), Ever the Diplomat: Confessions of a Foreign Office Mandarin, London: HarperPress.

HANNAY David (2013), Britain's Quest for a Role: A Diplomatic Memoir from Europe to the UN, London and New York: I.B. Tauris.

HURD Douglas (2004), Memoirs [2003], London: Abacus.

KNOTT Paul (2015), The Accidental Diplomat [2014, Kindle edition], Leeds, UK: Scratching Shed Publishing Ltd.

MEYER Christopher (2005), DC Confidential: The Controversial Memoirs of Britain's Ambassador to the U.S. at the Time of 9/11 and the Iraq War, London: Weidenfeld \& Nicolson.

MURRAY Craig (2006), Dirty Diplomacy: The Rough-and-Tumble Adventures of a Scotch-Drinking, SkirtChasing, Dictator-Busting and Thoroughly Unrepentant Ambassador Stuck on the Frontline of the War Against Terror, New York: Scribner.

RICKERD Martin (2012), The Patriotic Art [Kindle edition], Cirencester, Gloucestershire: Memoirs Publishing.

WATKINS Brian (2011), Feathers on the Brain! A Memoir, Vancouver, British Columbia: Hardwick Hill Publishing.

\section{AMERICAN DIPLOMATIC MEMOIRS}

BAUMAN Kirsten (2014), Accidental Patriot: A Diplomat's Journey in Africa Rediscovering America [Kindle edition], Scotts Valley, California: CreateSpace Independent Publishing Platform.

BULLINGTON James R. (2017), Global Adventures on Less-Traveled Roads: A Foreign Service Memoir [Kindle edition], North Charleston, SC: CreateSpace Independent Publishing Platform. 
FERCH John A. (2013), Fencing with Fidel and Other Tales of Life in the Foreign Service: A Selective Memoir [Kindle edition], Virginia: Miniver Press.

GROVE Brandon (2005), Behind Embassy Walls: The Life and Times of an American Diplomat, Columbia and London: University of Missouri Press.

HARSHA Stanley (2015), Like the Moon and the Sun: Indonesia in the Words of an American Diplomat [Kindle edition], Jakarta: Kompas Book Publisher.

HILl Christopher R. (2014), Outpost: Life on the Frontlines of American Diplomacy: A Memoir, New York: Simon \& Schuster.

LAWRENCE Malcolm (2003), Something Will Come Along: Witty Memoirs of a Foreign Service Officer with Nine Children [Kindle edition], Raleigh: Ivy House.

MABBATT Frederic S. (2013), On the Front Lines of the Cold War: The Adventures of an American Foreign Service Family [Kindle edition], Indianapolis: Dog Ear Publishing.

MCDONALD John W. (2008), The Shifting Grounds of Conflict and Peacebuilding: Stories and Lessons, Lanham, MD and Plymouth, UK: Lexington Books.

MEARA William (2006), Contra Cross: Insurgency and Tyranny in Central America, 1979-1989 [Kindle edition], Annapolis, Maryland: Naval Institute Press.

ORTIZ Frank V. (2005), Ambassador Ortiz: Lessons from a Life of Service, Albuquerque, New Mexico: University of New Mexico Press.

PERKINS Edward J. (2006), Mr Ambassador: Warrior for Peace, Norman, Oklahoma City, OK: University of Oklahoma Press.

SHEPARD William S. (2013), Sunsets in Singapore: A Foreign Service Memoir [Kindle edition], Seth B. Cutler Press.

TALBотт Strobe (2002), The Russia Hand: A Memoir of Presidential Diplomacy [Kindle edition], New York: Random House.

WILKowsкi Jean M. (2008), Abroad for her Country: Tales of a Pioneer Woman Ambassador in the U.S. Foreign Service, Notre Dame, Indiana: University of Notre Dame Press.

\section{SECONDARY REFERENCES}

ADAM Jean-Michel (1999), Linguistique textuelle : des genres de discours aux textes, Paris: Nathan. AUWERS Michael \& BILTEKIN Nevra (2012), “La diplomatie en mémoires. Étude sur les mémoires de diplomates belges et suédois du Xx ${ }^{\mathrm{e}}$ siècle”, L. BADEL, G. FERRAGU, S. JEANNESSON \& R. MELTZ (eds), Écrivains et diplomates, l'invention d'une tradition. XIX ${ }^{e}-\mathrm{XXI}^{e}$ siècles, Paris: Armand Colin, 181-192. BERRIDGE Geoffrey R. \& JAMES Alan (2001), A Dictionary of Diplomacy, Basingstoke and New York: Palgrave.

BERRIDGE Geoffrey R. (2010), Diplomacy: Theory and Practice [4 $4^{\text {th }}$ edition], Basingstoke: Palgrave Macmillan.

DER DERIAN James (1987), On Diplomacy: A Genealogy of Western Estrangement, Oxford: Basil Blackwell Press.

EGERTON George (ed.) (1994), Political Memoir: Essays on the Politics of Memory, London: Frank Cass \& Co. Ltd.

GENETTE Gérard (1982), Palimpsestes : la littérature au second degré, Paris: Seuil. 
GENETTE Gérard, BEN-ARI Nitsa \& MCHALE Brian (1990), “Fictional Narrative, Factual Narrative", Poetics Today, 11(4), 755-774.

HART Francis Russell (1979), “History Talking to Itself: Public Personality in Recent Memoir”, New Literary History, 11(1), 193-210.

JEANNELLE Jean-Louis (2008), Écrire ses Mémoires au XX siècle : déclin et renouveau, Paris: Gallimard. MAINGUENEAU Dominique (2004), “Retour sur une catégorie : le genre”, J-M. ADAM, J-B. GRIZE \& M. Ali BOUACHA (eds), Texte et discours : catégories pour l'analyse, Dijon: Éditions Universitaires de Dijon, 107-118.

NEUMANN Iver (2012), At Home with the Diplomats, Ithaca, NY and London: Cornell University Press. PETIT Michel (1999), "La fiction à substrat professionnel : une autre voie d'accès à l'anglais de spécialité”, ASp (23-26), 57-81, <http://asp.revues.org/2325> (12 September 2017).

QUINBY Lee (1992), “The Subject of Memoirs: The Woman Warrior's Technology of Ideographic Selfhood", S. SMITH \& J. WATson (eds), De/Colonizing the Subject: The Politics of Gender in Women's Autobiography, Minneapolis: University of Minnesota Press, 297-320.

RAK Julie (2004), “Are Memoirs Autobiography? A Consideration of Genre and Public Identity”, Genre, 36, 305-326.

RANA Kishan S. (2011), 21 ${ }^{\text {st }}$ Century Diplomacy: A Practitioner's Guide, London and New York: Continuum.

SABER Anthony (2006), Les milieux militaires américains et leurs discours (doctoral thesis), Université Bordeaux 2, Bordeaux.

SHARP Paul (2004), “The Idea of Diplomatic Culture and its Sources”, H. SLAVIK (ed.), Intercultural Communication and Diplomacy, Malta and Geneva: DiploFoundation, 361-379, <https:// www.diplomacy.edu/resources/general/idea-diplomatic-culture-and-its-sources> (12 September 2017).

STEINER Zara (1994), “The Diplomatic Life: Reflections on Selected British Diplomatic Memoirs Written Before and After the Great War", G. EGERTON (ed.), Political Memoir: Essays on the Politics of Memory, London: Frank Cass \& Co. Ltd, 167-187.

WARE B.L. \& LINKUGEL Wil A. (1973), “They Spoke in Defense of Themselves: On the Generic Criticism of Apologia", Quarterly Journal of Speech, 59(3), 273-283.

WISEMAN Geoffrey (2005), "Pax Americana: Bumping into Diplomatic Culture”, International Studies Perspectives, 6(4), 409-430.

\section{NOTES}

1. CECIL Robert (Lord Salisbury) (1905), Essays by the Marquess of Salisbury: vol 1, biographical, London: John Murray, 3-70.

2. Our corpus references can be found in full at the end of this paper.

3. Loosely translated from: "Les Mémoires [...] sont le récit d'une vie dans sa condition historique: un individu y témoigne de son parcours d'homme emporté dans le cours des événements, à la fois acteur et témoin, porteur d'une histoire qui donne sens au passé." 
4. Loosely translated from: "Les genres discursifs peuvent être considérés comme des 'catégories prototypiques-stéréotypiques [...] définissables par des tendances ou des gradients de typicalité, par des faisceaux de régularités et des dominantes plutôt que par des critères très stricts'."

5. Loosely translated from : “[...] il présente un statut particulier, hybride, qui l'apparente aux discours spécialisés, sans en faire pour autant un véritable discours spécialisé au sens habituel. Il comporte en effet un certain nombre de caractéristiques des discours spécialisés (terminologiques, phraséologiques, etc.), mais ne relève pas d'un genre ou d'un type reconnu de discours spécialisé."

\section{ABSTRACTS}

This paper puts forward a preliminary analysis of the diplomatic memoir as a genre, based on research on the specialised language, discourse and culture of the professional domain of diplomacy. We draw on a corpus of 28 British and American diplomatic memoirs published since 2000 in order to define a "generic prototype" for this type of text. We then examine the "professional substratum" of the diplomatic memoir and how diplomatic practice, knowledge, and linguistic specificities are described, before exploring the possible intersections between these professional life narratives and professional "diplomatic culture".

Cet article propose une analyse préliminaire des mémoires de diplomates dans le cadre d'une recherche sur la langue-culture spécialisée du domaine professionnel de la diplomatie. Nous nous appuyons sur un corpus de 28 mémoires de diplomates britanniques et américains publiés depuis 2000 afin de définir un "prototype générique " pour ce type de texte. Nous examinons ensuite le «substrat professionnel» des mémoires diplomatiques afin d'étudier comment les pratiques, les connaissances et les spécificités langagières du domaine diplomatique sont décrites. Enfin, nous explorons les convergences possibles entre ces récits de vie professionnelle et la « culture diplomatique».

\section{INDEX}

Keywords: memoir, diplomacy, genre analysis, diplomatic culture, specialised language

Mots-clés: mémoires, diplomatie, analyse de genre, culture diplomatique, langue spécialisée

\section{AUTHOR}

JESSICA STARK

Aix-Marseille Univ., LERMA, ED 354, Aix-en-Provence, France 